Original Paper

\title{
Pengembangan Profesionalissme Guru dalam Menulis Karya Ilmiah
}

\author{
Kasnawi Al Hadi ${ }^{1}$, Nurul Qomariyah ${ }^{1 *}$, Suhayat Minardi ${ }^{1}$, Laili Mardiana ${ }^{1}$, Alfina \\ Taurida Alaidrus ${ }^{1}$, Siti Alaa' ${ }^{1}$
}

${ }^{1}$ Progam Studi Fisika, Fakultas MIPA, Universitas Mataram, Mataram, Indonesia.

*Corresponding Author: Nurul Qomariyah: Program Studi Fisika Fakultas MIPA, Universitas Mataram, Indonesia.

Email: nurulqomariyah@unram.ac.id

\begin{abstract}
Salah satu bentuk profesionalisme guru adalah memiliki kemampuan menulis artikel ilmiah. Guru SMP 2 Sekotong pada umumnya belum memiliki wawasan yang cukup tentang kepenulisan ilmiah sehingga guru mengalami kesulitan dalam meningkatkan kemampuan profesionalnya dalam bidang kepenulisan. Tujuan kegiatan pengabdian pada masyarakat ini adalah meningkatkan kompetensi guru dalam menulis karya ilmiah. Metode yang digunakan adalah pendekatan konstruktivisme, pelaksanaan kegiatan dibagi menjadi dua kali yaitu pertama pelaksanaan kegiatan dilakukan melailui pemberian materi di dalam kelas dengan metode ceramah kelas, diskusi, pemberian contoh dan latihan, dan selanjutnya peserta diberikan layanan bimbingan. Hasil yang diperoleh dari kegiatan ini adalah menambah pengetahuan dan wawasan yang cukup tentang hakikat penulisan artikel ilmiah, menambah keterampilan menulis karya tulis ilmiah berdasarkan sistematika dan bahasa ilmiah yang baik. Guru SMP 2 Sekotong yang mengikuti kegiatan pengabdian masyarakat sangat antusias mendapat pelatihan tentang teknik penulisan karya tulis ilmiah sebagai penunjang profesionalitasnya didunia pendidikan serta dapat menghasilkan produk artikel ilmiah yang layak diterbitkan di jurnal ilmiah.
\end{abstract}

Keywords: Artikel ilmiah, guru, Konstruktivisme

\section{Pendahuluan}

Profesi guru sebagai pendidik merupakan jabatan professional, salah satu bentuk keprofesionalannya guru dituntut untuk berkembang sesuai dengan perkembangan jaman, ilmu pengetahuan dan teknologi. Hal ini juga di atur dalam Keputusan Menteri Negara Pendayagunaan Aparatur Negara nomor 84/1993 tentang Jabatan Fungsional Guru dan Angka Kreditnya. Dalam keputusan terebut diamanatkan seorang guru dituntut berprestasi melalui menulis karya ilmiah agar dapat membelajarkan anak didik yang memiliki kualitas unggul. Berdasarkan hasil studi pendahuluan yang dilakukan melalui wawancara kepada guru-guru dan kepala sekolah SMP 2 Sekotong Kabupaten lombok Barat, menunjukkan bahwa belum banyak yang memiliki karya ilmiah sebagai wujud kemampuan profesionalnya.
Pengembangan profesionalisme guru dalam menulis karya ilmiah pada prinsipnya bertujuan untuk membina karier kepangkatan dan profesionalisme guru. Penggunaan angka kredit sebagai salah satu persyaratan seleksi peningkatan karir, bertujuan memberikan penghargaan secara lebih adil dan lebih professional terhadap kenaikan pangkat yang merupakan pengakuan profesi untuk kemudian memberikan peningkatan kesejahteraannya. Dalam SK Menpan. No. 84/Menpan/1993 tentang jabatan fungsional guru menyebutkan bahwa salah satu bidang kegiatan jabatan fungsional guru adalah Bidang Pengembangan Profesi. Salah satu jenis kegiatan pengembangan profesi guru adalah melakukan kegiatan karya tulis ilmiah yang salah satunya dapat berupa Karya ilmiah hasil penelitian yang dipublikasikan. Berdasarkan Sujana dan Laksana 2004 mengulas bahwa penetapan angka kredit memberi makna yang amat mulia: Memberikan motivasi yang tinggi bagi guru untuk berkompetisi secara sehat dalam mengembangkan karir mencapai pangkat setinggi-tingginya, merupakan proses 
seleksi terciptanya guru-guru yang betul-betul berprestasi sesuai dengan tugas yang diembannya, Tercapainya suatu pola pembinaan prestasi dan karir guru secara objektif, terkoordinasi, terpadu dan konseptual.

Penulisan karya tulis ilmiah yang akan dilatihkan pada kegiatan ini adalah karya tulis guru dari penelitian dan non peneitian serta cara menemukan gagasan ilmiah dari telaah pustaka. berdasarkan Djuroto dan Supriyadi (2007) yang menyatakan bahwa suatu karya tulis ilmiah dapat dikatagorikan dalam dua kelompok yaitu: (1) karya tulis ilmiah yang merupakan laporan hasil penelitian, dan (2) karya tulis ilmiah yang berupa tinjauan, ulasan, atau gagasan ilmiah. Meskipun keduanya berbeda, namun sebagai tulisan yang bersifat ilmiah terdapat beberapa ciri yang menunjukkan kesamaan, yaitu: (1) hal yang dipermasalahkan berada pada kawasan pengetahuan keilmuan, (2) kebenaran isinya mengacu kepada kebenaran ilmiah, (3) kerangka sajiannya mencerminan penerapan metode ilmiah, dan (4) tampilan fisiknya sesuai dengan tata cara penulisan karya (Nurudin, 2007).

Pelatihan ini dilakukan dengan tujuan untuk meningkatkan kompetensi profesional akademik dalam menulis artikel ilmiah sehingga guru menjadi aktif, kreatif dan profesional dalam menjalankan tugasnya. Dengan demikian guru yang aktif-kreatif berkarya dalam menulis karya ilmiah tersebut, pastilah akan memperoleh angka kredit yang memungkinkan untuk syarat kenaikan pangkat atau jabatan fungsional. Di SMPN 2 Sekotong Kabupaten Lombok Barat terdapat jumlah guru sebanyak 31 orang. Dari sudut kepangkatan sebagian besar $(60 \%)$ di antara mereka masih menduduki golongan III. Relatif sedikit guru yang berhasil naik pangkat hingga menduduki Golongan IV/a apalagi IV/b.

Kendala utama yang dihadapi mitra adalah sulitnya mengumpulkan angka kredit pada komponen penulisan karya ilmiah. Hal ini dipicu dari keadaan para guru yang belum memiliki wawasan cukup tentang kepenulisan serta belum terbiasa melakukan penelitian. Oleh karena itu melalui kegiatan Pengabdian Pada Masyarakat (PPM) ini kami bentuk sebuah Tim dari Prodi Fisika Unram untuk membantu memberikan pelatihan penulisan karya ilmiah bagi Guru SMPN 2 Sekotong Kabupaten Lombok Barat.

\section{Metode Pelaksanaan}

Peaksanaan pengabdian ini dibagi menjadi beberapa tahapan yaitu: 1) melakukan analisis kebutuhan mitra, 2) menyusun rancangan pelatihan, 3) melaksanakan kegiatan pengabdian kepada masyarakat, dan 4) evaluasi poses dan hasil kegiatan pengabdian kepada masyarakat. Metode yang digunakan selama pendampingan adalah pendekatan Konstruktivisme dimana pada pelaksanaan kegiatan dilakukan melailui pemberian materi di dalam kelas dengan metode ceramah kelas, diskusi, pemberian contoh dan latihan. Materi kegiatan secara umum mengenai pengembangan profesionalisme Guru untuk menghasilkan karya tulis ilmiah untuk meningkatkan kemampuan guruguru menghasilkan suatu tulisan ilmiah. Kegiatan selanjutkan dilakukan dengan metode melalui layanan bimbingan kepada peserta pelatihan dalam menyusun tulisan ilmiah yang baik secara intensif dengan komonikasi antara tim PPM dan mitra, agar waktu dan pelaksanaan dapat berjalan efektif dan efisien.

Evaluasi dalam kegiatan ini dibagi menjadi evaluasi proses dan evaluasi efektivitas kegiatan. Evaluasi proses dilihat dari keaktifan peserta kegiatan selama kegiatan berlangsung baik ketika kegiatan pemberian materi di dalam kelas serta antusias peserta dalam melakukan layanan bimbingan secara komonikasi pribadai kepada tim PKM. Efektifitas kegiatan dilihat dari pemahaman peserta pelatihan dalam menulis karya tulis ilmiah yang menjadi indikatornya adalah penguasaan konsep peserta dalam menyusun karya tulis ilmiah, ketepatan struktur tulisan ilmiah, serta kode etik tulisan ilmiah dalam mengutip referensi dan pustaka sebagai literature menulis. Produk dari hasil kegiatan ini adalah kemampuan peserta dalam menulis karya ilmiah yang layak dipublikasikan pada jurnal ilmiah.

\section{Hasil dan Pembahasan}

Pengabdian pada masyarakat dengan tema meningkatkan kemampuan menulis melalui pelatihan penulisan karya ilmiah bagi guru-guru di SMP 2 Sekotong Kabupaten Lombok Barat dilaksanakan pada tanggal 20 Oktober 2018. Jumlah peserta pelatihan ini adalah 20 orang. Khalayak sasaran dalam kegiatan pengabdian pada masyarakat memiliki antusiasme dan dukungan 
yanag tinggi. Hal ini terlihat dari dukungan berupa ketersediaan tempat dan fasilitas penunjang demi kelancaran kegiatan.

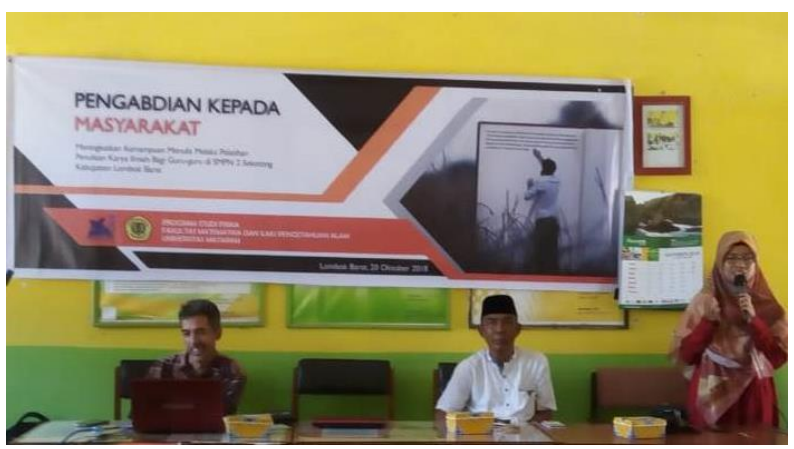

(a)

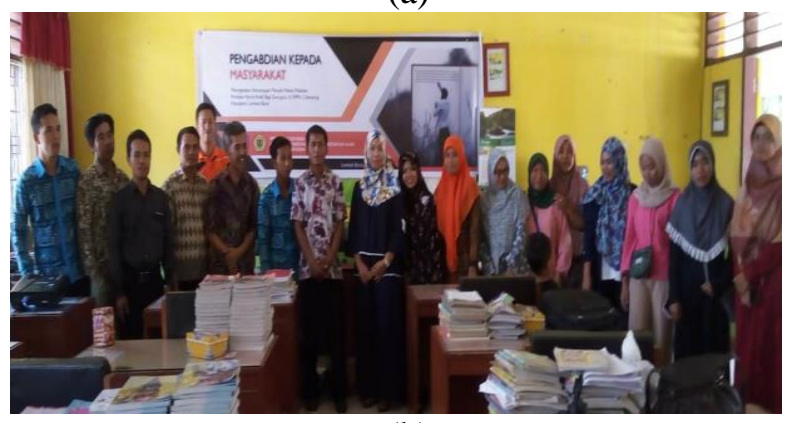

(b)

Gambar 1. Kegiatan pembukaan oleh Kepala sekolah SMP 2 Sekotong (a). peserta dan tim PPM (b)

Materi yang diberikan saat kegiatan yaitu 1) pentingnya pengembangan profesionalisme Guru, 2) Teknik menulis karya ilmiah, 3) Struktur dan outline penulisan karya ilmiah yang sitematik, 4) Kode etik penulisan karya ilmiah, 5) strategi menemukan gagasan ilmiah dari referensi dan 6) Perhitungan angka kredit dari karya tulis ilmiah bagi guru. Kegiatan suasana kelas saat pemberian materi dapat dilihat pada gamnar 2 dibawah.

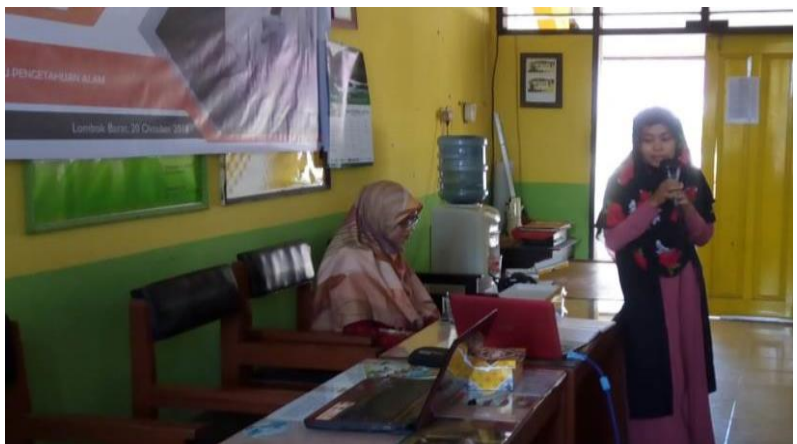

Gambar 2. Pemberian materi oleh tim PPM

Peserta sangat antusias dalam menerima materi yang diberikan terlihat dari rasa ingin tahu yang tinggi dari peserta dengan berbagai pertanyaan mengenai ha-hal mendasar terkait penulisan karya ilmiah terhadap pengembangan profesi guru, contohnya pertanyaan yang diajukan oleh bapak Arif selaku pengajar mata pelajaran Fisika di SMP 2 Sekotong "bagaimana cara menemukan gagasan ilmiah dan cara menuangkan dalam bentuk tulisan ilmiah". Suasana kelas saat pemberian materi dapat dilihat pada gambar 3 .
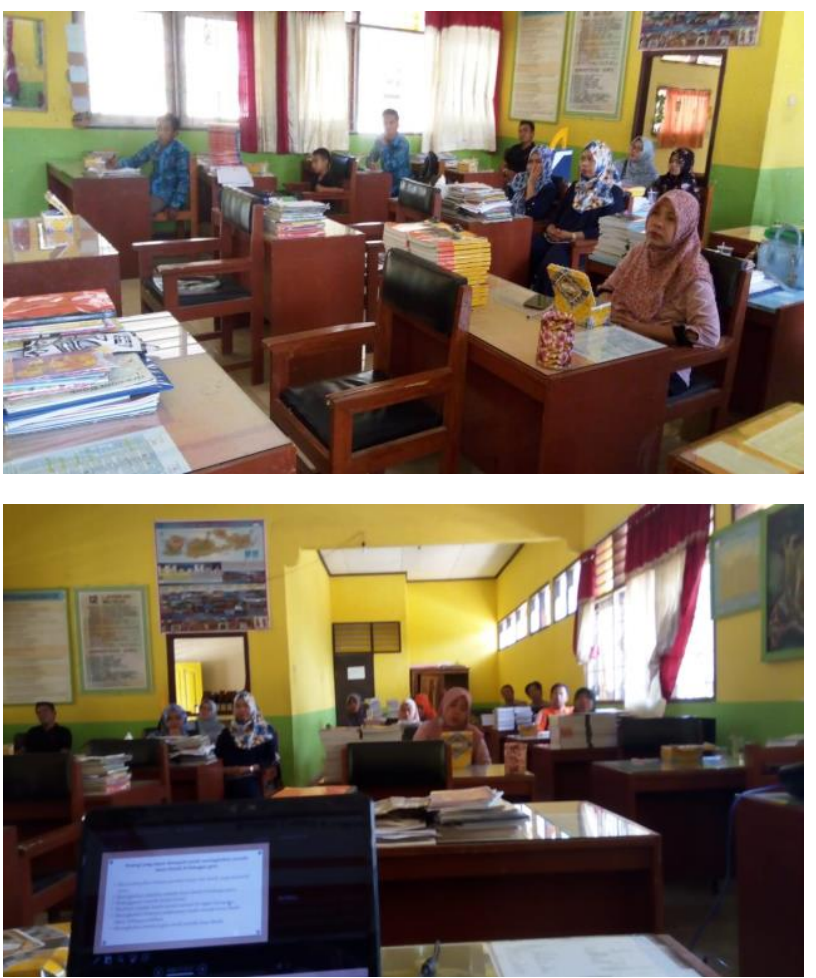

Gambar 3. Suasana kelas saat pemberian materi

Hasil kegiatan pengabdian kepada masyarakat ini yaitu: 1) Menambah pengetahuan dan wawasan yang cukup tentang hakikat penulisan artikel ilmiah bagi guru-guru SMP 2 Sekotong, 2) Menambah pengetahuan dan keterampilan menulis karya tulis ilmiah berdasarkan struktur dan Bahasa ilmiah yang baik bagi guru-guru SMP 2 Sekotong dengan menerapkan Kode etik menulis artikel ilmiah, 3) Menambah keterampilan menulisan artikel ilmiah berbasis penelitian maupun kajian pustaka, dan 4) Guru SMP 2 Sekotong yang mengikuti kegiatan pengabdian masyarakat sangat antusias mendapat pelatihan tentang teknik penulisan karya tulis ilmiah sebagai penunjang profesionalitasnya didunia pendidikan sebagai salah satu syarat kenaikan pangkat. 
Peserta pelatihan sangat serius dan antusias dalam mengikuti kegiatan. Bentuk keseriusan dan antusias peserta dapat dilihat dari keaktifan bertanya serta mengerjakan latihan-latihan yang diberikan saat pelatihan. Kegiatan ini mampu meningkatkan motivasi guru dalam menulis. Selain itu juga dapat memberikan pengetahuan kepada guru tentang tata cara penulisan artikel ilmiah dan manfaatnya. Dengan kegiatan ini, guru mendapatkan pengalaman langsung dalam menulis artikel ilmiah.

Namun demikian, kegiatan penulisan karya ilmiah itu sangat penting untuk dilakukan oleh guru tidak hanya dalam rangka perolehan angka kredit untuk kenaikan jabatan dan uji sertifikasi saja, tetapi terlebih lagi dilakukan terutama dalam rangka peningkatan kualitas guru sebagai tenaga yang profesional. Harus dipahami bahwa guru profesional yang layak diapresiasi tinggi itu adalah guru yang menjadi pelaku aktif sebuah proses pembentukan ilmu pengetahuan (knowledge construction).

Terdapat beberapa faktor penyebab kurangnya antusiasme guru dalam mengembangkan prefesionalismenya khusunya dalam menghasilkan karya tulis ilmiah, diantaranya adalah kurang kondusifnya iklim sekolah untuk menjadikan guru sebagai peneliti merupakan faktor utama yang menyebabkan realitas seperti ini. Hal ini pula yang banyak dirasakan oleh guru-guru di SMP 2 Sekotong Lombok Barat. Hal yang lain adalah para guru sudah merasa cukup dengan kerja utama yang sering dilakukan yaitu mengajar di dalam kelas, hal ini dikarenakan lingkungan sekitar mereka juga "tak menuntut" banyak dari para guru, kurangnya fasilitas untuk melakukan penelitian di sekolah adalah bentuk lain dari kurang kondusifnya suasana sekolah terkait penelitian ini. Terbatasnya referensi, tidak adanya jurnal penelitian di sekolah, dan tidak teralokasinya dana khusus untuk penelitian. Hal-hal tersebut merupakan penyebab tidak kondusifnya dunia penelitian di sekolah selama ini.

Pengembangan profesi guru dalam menulis karya ilmiah sebenarnya merupakan tugas dan kebutuhan dalam melaksanakan tugasnya di dunia pendidikan. Oleh karena itu guru harus terus menambah wawasan dan pengembangan diri dalam melaksanakan tugasnya secara utuh. Beberapa alasan yang melatar belakangi perlunya pengembangan kemampuan menulis karya ilmiah bagi guru, yakni: (1) guru sebagai insan terpelajar, (2) guru sebagai agen pembaharu, (3) guru sebagai pendorong dan mitra siswa dalam menulis karya ilmiah, (4) guru sebagai peneliti (terutama PTK), dan (5) guru sebagai penulis karya ilmiah. Lima alasan tersebut menguatkan bahwa guru perlu terus-menerus belajar mengembangkan kemampuannya dalam menulis karya ilmiah (Sudjana dan Laksana, 2004).

\section{Kesimpulan}

Berdasarkan hasil kegiatan pengabdian pada masyarakat di SMP 2 Sekotong mengenai pengembangan profesionalisme guru dalam menulis artikel ilmiah, maka dapat disimpulkan kegiatan pengabdian dilaksanakan dengan baik. Kegiatan dapat dilihat pada peserta pelatihan dapat menambah pengetahuan dan keterampilan peserta didik dalam penulisan artikel ilmiah yang layak untuk dipublikasikan sesuai dengan sistematika d penulisan ilmiah yang baik dan benar serta sesuai dengan etika ilmiah. Kegiatan ini juga memberikan manfaat pengalaman belajar baru terkait dengan motode penulisan artikel ilmiah, sehingga meningkatkan kemampuan menulis.

\section{Saran}

Pengabdian pengembangan profesionalisme Guru dalam menulis artikel ilmiah melaui Pelatihan Penulisan Karya Ilmiah Bagi Guru-Guru di SMP 2 Sekotong Kabupaten Lombok Barat hendaknya terus ditingkatkan agar kualitas guru semakin baik dalam menulis karya ilmiah sehingga dapat memberikan dampak pada pembelajaran yang semakin berkualitas. Perlu dilakukan berbagai pelatihan dalam bentuk lokakarya penulisan karya ilmiah bagi guru yang dilakukan oleh berbagai pihak seperti Depdiknas, LPMP, Dinas Pendidikan, dan Perguruan Tinggi sehingga kemampuan guru dalam menulis karya ilmiah semakin luas dan terasah.

\section{Daftar Pustaka}

Aisyah, E.N., dan Mahanani, P. 2017. Pelatihan Menulisan Artikel Ilmiah Bagi Guru Sekolah Dasar Dan Taman Kanak-Kanak 
Kecamatan Tajinan Kabupaten Malang. Abdimas Padagogi. 1(1).

Djuroto, T., dan Supriyadi, B. 2007. Menulis Artikel dan Karya Ilmiah. Bandung: Remaja Rosda Karya.

Nurudin. 2007. Dasar-dasar Penulisan. Malang: UMM Press.

Sudjana, N., dan Laksana, U. 2004. Menyusun Karya Tulis Ilmiah untuk Memperoleh Angka Kredit. Bandung: Sinar Baru Algesindo.

Keputusan Menteri Negara Pendayagunaan Aparatur Negara Nomor 84 Tahun 1993 tentang Penetapan Jabatan Fungsional Guru dan Angka Kreditnya. 2000. Jakarta: Kementerian Negara Pendayagunaan Aparatur Negara.

Sulipan. 2007. Kegiatan Pengembangan Profesi Guru.

http://www.ktiguru.org/index.php/profesi guru diakses tanggal 10 Mei 2018. 